\title{
KERAJAAN ALLAH SEBAGAI INTI KEHIDUPAN DAN PERUTUSAN YESUS
}

\author{
Martin Chen*
}

\begin{abstract}
The Kingdom of God is central to the whole message of Jesus Christ. Through the kingdom of God, we can discover and understand the entire mission of Jesus. The Kingdom of God is the embodiment of God's saving presence in human life. Compared with the Jewish religious movements of that era, especially the apocalyptic movement, which also awaited the coming of the Kingdom of God, Jesus' preaching about the kingdom of God has a special feature, that the Kingdom of God is an act of forgiveness and salvation from God, and not God's judgment; moreover, the action is happening now in people's life, rather than being something that is expected in the future. Through Jesus, through his word and his work, God is now present in the midst of the people. Through his parables and his words in the Sermon on the Mount and in the act of casting out demons, in healing the sick and in the forgiveness of sin, Jesus reveals the presence of a compassionate God, a God who frees people from the power of sin and leades them in the power of divine grace. Jesus not only preached the kingdom of God but gave himself so that people would experience God's saving work. Through His death on the cross, Jesus freely poured God's mercy and goodness upon human beings. Jesus' proclamation of the kingdom of God has important implications for the understanding of the Christological and ecclesiological renewal.
\end{abstract}

Keywords: Kingdom of God, salvation, forgiveness, word of Jesus, work of Jesus, human life, Christological and ecclesiological renewal.

Abstrak: Kerajaan Allah merupakan inti seluruh pewartaan Yesus Kristus. Melalui Kerajaan Allah kita dapat menemukan dan mengerti seluruh perutusan hidup Yesus. Kerajaan Allah berarti perwujudan kehadiran Allah yang menyelamatkan dalam hidup manusia. Dibandingkan dengan gerakan keagamaan yahudi pada zaman itu,

* Martin Chen, Program Studi Teologi, Sekolah Tinggi Keguruan dan Ilmu Pendidikan St.Paulus Ruteng, P.O. Box 801, Ruteng 86508. E-mail:martinochen@hotmail.com. 
khususnya apokaliptik yang juga menantikan kedatangan Kerajaan Allah, pewartaan Yesus tentang Kerajaan Allah memiliki ciri khusus bahwa Kerajaan Allah adalah tindakan pengampunan dan penyelamatan Allah, bukan penghakiman Allah dan tindakan itu kini terjadi nyata dalam hidup manusia, dan bukannya sesuatu yang dinantikan di masa depan. Melalui diri Yesus, dalam sabda dan karya-Nya, Allah kini hadir di tengah-tengah umat-Nya. Lewat perumpamaan dan sabda bahagia maupun dalam tindakan pengusiran setan, penyembuhan orang sakit dan pengampunan orang berdosa, Yesus menyatakan kehadiran Allah yang penuh belas kasih dalam hidup manusia, yang membebaskannya dari kuasa dosa dan menuntunnya dalam kuasa rahmat Ilahi. Yesus tidak hanya memberitakan Kerajaan Allah tetapi juga memberikan diri-Nya, sehingga orang sungguh mengalami karya penyelamatan Allah. Melalui kematian-Nya di salib, Yesus mencurahkan dengan cuma-cuma kerahiman dan kebaikan Allah dalam hidup manusia. Pewartaan Kerajaan Allah Yesus ini memiliki dampak penting bagi pembaruan pemahaman kristologis dan eklesiologis.

Kata-kata Kunci: Kerajaan Allah, penyelamatan, pengampunan, sabda Yesus, karya Yesus, kehidupan manusia, pembaruan pemahaman kristologis dan eklesiologis.

\section{PENDAHULUAN}

Fenomena menarik dalam dunia dewasa ini adalah munculnya kesadaran baru akan dimensi religiositas dalam kehidupan manusia meskipun arus sekularisasi masih terus mengalir deras. Berkaitan dengan agama Kristen (Katolik) hal ini misalnya dapat diamati dalam gerakan dan usaha pencarian baru untuk semakin mengenal secara mendalam tokoh sentralnya, yaitu Yesus Kristus. Kita tentu masih ingat film dari Mel Gibson "Yesus Kristus" yang memukau publik global beberapa tahun lalu. Kemudian buku terbitan Paus Benediktus XVI yang berjudul “Yesus dari Nasaret" (2007) menempati posisi "best seller" beberapa minggu di Eropa dan Amerika. Tampaknya Si Tukang Kayu dari Nasaret, Galilea, ini meskipun telah meninggal hampir 2000 tahun yang silam tetap 
memiliki daya pikat luar biasa dan menjadi sumber inspirasi serta kekuatan bagi tak terbilang manusia sepanjang sejarah.

Lalu, apakah yang menjadi magnet Yesus yang menarik begitu banyak orang? Apakah yang menjadi inti pewartaan hidup-Nya? Umumnya kebanyakan orang menemukan isi pewartaan Yesus dalam cinta kasih terhadap Allah dan sesama. Selain itu ada pula yang melihat misi utama kehadiran-Nya di bumi untuk menebus manusia dari dosa. Orang kagum akan peristiwa kematian-Nya di salib membaca pesan hidup-Nya dalam ajaran perjuangan tanpa kekerasan; dan yang terpesona dengan peristiwa kebangkitan-Nya merindukan saat datangnya kehidupan kekal dari-Nya. Semua hal ini tentu tidaklah salah, karena tema-tema ini berkaitan dengan kehidupan Yesus. Namun pertanyaan utama yang tetap muncul adalah manakah yang menjadi tema sentral pewartaan Yesus dan sejauh mana hal itu didukung oleh sumber-sumber biblis?

Hal yang menjadi konsensus umum para ekseget dan teolog dewasa ini adalah bahwa Kerajaan Allah merupakan inti pewartaan Yesus. Seluruh hidup, karya dan sabda Yesus terpusat pada Kerajaan Allah. Penginjil Markus mengungkapkan isi seluruh warta keselamatan Yesus langsung pada awal injilnya: "Waktunya telah genap, kerajaan Allah sudah dekat" (Mrk 1,15). Ayat ini dapat diartikan sebagai prolog sekaligus ringkasan singkat seluruh pewartaan Yesus, yang ingin Markus uraikan dalam injilnya sekaligus yang menjadi titik tolak seluruh isi injilnya. ${ }^{1}$ Kerajaan Allah ibarat benang merah yang merangkai seluruh pewartaan Yesus menjadi satu kesatuan dan melalui Kerajaan Allah ini kita dapat mengenal dan berjumpa dengan Yesus dari Nasaret yang sesungguhnya.

\section{ISTILAH KERAJAAN ALLAH}

Betapa pentingnya Kerajaan Allah dalam Perjanjian Baru tampak dalam kenyataan bahwa istilah ini muncul 162 kali. Dari hasil penelitian

1 G.R. Beasley-Murray, Jesus and the Kingdom of God (Michigan-Devon: Wm. B. Eerdmans, 1986), p. 71. 
biblisnya, Helmut Merklein, ekseget Jerman, menyatakan bahwa istilah Kerajaan Allah terutama digunakan dalam injil sinoptik: Injil Matius 55 kali, Injil Markus 20 kali dan Injil Lukas 64 kali (ditambah dalam Kisah para Rasul 8 kali). ${ }^{2}$ Istilah yang paling sering dipakai adalah "Kerajaan Allah" dan "Kerajaan Surga." Kadang-kadang digunakan juga istilah "Kerajaan Bapa" atau "Kerajaan-Nya". ${ }^{3}$

Khususnya penginjil Matius menggunakan istilah Kerajaan Surga dan bukannya Kerajaan Allah. Kebanyakan ahli Kitab Suci melihat alasannya dalam diri para pendengar atau jemaat Matius yang umumnya orang Yahudi yang berusaha menghindari penggunaan langsung kata Allah. Mereka tidak menyebut langsung nama Allah karena memiliki rasa hormat yang mendalam pada Allah. ${ }^{4}$ Namun argumen ini tidak didukung oleh kenyataan bahwa Matius sendiri empat kali menggunakan istilah Kerajaan Allah (Mat 12:28; 19:24; 21:31,43). Karena itu, menurut Joachim Gnilka, ekseget dari Universitas Munich, dengan istilah Kerajaan Surga, penginjil Matius ingin melukiskan dimensi kuasa universal yang meliputi alam semesta dari Kerajaan Allah yang sedang datang. ${ }^{5}$

Hasil analisis bahasa menunjukkan adanya perkembangan arti dalam penggunaan istilah Kerajaan Allah. ${ }^{6}$ Pertama-tama, Kerajaan Allah berarti kekuasaan dinamis Allah atau pelaksanaan aktif kuasa Kerajaan-Nya. Arti ini ditemukan terutama dalam lapisan-lapisan tua Injil (sumber $Q$ dan Markus). Kalimat dengan arti ini keluar dari mulut Yesus dalam bentuk: Subjek (Kerajaan Allah) + Kata kerja yang menunjukkan gerakan dinamis. Misalnya: Kerajaan Allah “yang sudah dekat” (Luk 10:9; Mat

2 Helmut Merklein, Jesu Botschaft von der Gottesherrschaft: Eine Skizze (Stuttgart: Katholisches Bibelwerk, 1989), S. 17.

3 Helmut Merklein, Jesu Botschaft, S. 18.

4 Kemungkinan besar menurut ekseget Merklein, Yesus menggunakan istilah Kerajaan Allah yang dalam Bahasa Aramnya malekuta dan Bahasa Ibraninya malekut. Penggunaan istilah Kerajaan Surga (malekut schamajim) oleh Matius sesuai dengan rasa hormat dan segan jemaat Kristen Yahudi terhadap penggunaan nama Allah. Helmut Merklein, Jesu Botschaft, S. 37.

5 Joachim Gnilka, Jesus von Nazaret: Botschaft und Geschichte (Freiburg-Basel-Wien: Herder, 1990), S. 88.

6 Helmut Merklein, Jesu Botschaft, SS. 18-19. 
10:7), “datang" (Luk 11:2; Mat 6:10), "sudah datang" (Luk 11:20; Mat 12:28), "diberitakan" (Luk 16:16; Mat 11:12a). Khususnya dalam perumpamaan tentang biji sesawi (Mrk 4:30-32) dan tentang benih yang tumbuh (Mrk 4:26-29) dapat ditemukan arti Kerajaan Allah sebagai perwujudan aktif kuasa Allah. Kerajaan Allah tampil sebagai sesuatu yang maha agung yang sedang bertindak aktif. Di sini yang dibicarakan bukanlah sebuah ruangan atau sesuatu yang statis tetapi sesuatu yang aktif-dinamis, yang menunjuk kepada perwujudan kekuasaan Allah. ${ }^{7}$

Kemudian dalam lapisan lapisan Injil yang lebih muda Kerajaan Allah digunakan dalam arti yang lebih statis, yaitu sebagai situasi keselamatan. Di sini Kerajaan Allah dikaitkan dengan situasi keselamatan eskatologis/paripurna dan digunakan dalam arti yang analog dengan kehidupan kekal. Misalnya: masuk ke dalam Kerajaan Surga (Mat 5:20; 7:21), Kerajaan Allah adalah sesuatu yang diwarisi (Mat 25:34; bdk. Mat 5:5), yang dilihat (Mrk 9:1), yang disambut (Mrk 10:15) atau yang dicari (Luk 12:31). ${ }^{8}$ Dalam hal ini, Kerajaan Allah menyatakan sebuah situasi, di mana merajanya Allah sepenuhnya diakui manusia dan terwujud dalam segala tingkatan kehidupannya. ${ }^{9}$

\section{CIRI KHAS PEWARTAAN KERAJAAN ALLAH YESUS}

Pewartaan Kerajaan Allah Yesus tidak terlepas dari konteks pemahaman dan penghayatan Kerajaan Allah dalam tradisi kehidupan umat Israel. Baik dalam Perjanjian Lama maupun dalam gerakan-gerakan keagamaan Yahudi pada zaman Yesus, terdapat harapan besar akan kedatangan Kerajaan Allah. Tetapi Yesus tidak sekedar mengulangi pewartaan yang ada saat itu, tetapi ia juga meradikalisasikannya sekaligus memberikan tekanan yang sama sekali baru. Manakah ciri khas pewartaan Kerajaan Allah Yesus?

7 Menurut Merklein sifat dinamis istilah Kerajaan Allah inilah yang rupanya menjadi alasan utama mengapa Yesus menggunakannya sebagai tema sentral pewartaan eskatologisnya. Helmut Merklein, Jesu Botschaft, S. 38.

8 Helmut Merklein, Jesu Botschaft, S. 22.

9 Medard Kehl, Dein Reich komme: Eschatologie als Rechenschaft über unsere Hoffnung (Kevelaer: Topos, 2003), S. 137. 


\section{Isi Pewartaan Kerajaan Allah yaitu Karya Penyelamatan Allah}

Hal utama yang memberikan ciri khas pewartaan Yesus adalah penyelamatan. Bagi-Nya Kerajaan Allah berarti pemenuhan rencana penyelamatan Allah. ${ }^{10}$ Melalui warta Kerajaan Allah, Yesus memaklumkan bahwa Allah kini hadir untuk menyelamatkan umat-Nya. Yesus memang sependapat dengan Yohanes Pembaptis bahwa Israel berada dalam situasi ketidakselamatan akibat dosa-dosanya dan jatuh dalam situasi penghakiman oleh Allah. Karena itu, Yesus menuntut pertobatan mendasar umat Israel (bdk. Luk 13:1-5; 12:16-20; 11:31). Tetapi yang menjadi pusat pewartaan Yesus bukanlah pengadilan Allah melainkan kerahiman Allah. Berbeda dari Yohanes Pembaptis yang menekankan hukuman dari Allah, Yesus menyampaikan kepada umat Israel yang berdosa warta keselamatan tetang Kerajaan Allah. Israel, yang mewakili seluruh bangsa di muka bumi, tidak lagi berada dalam murka Allah tetapi dalam rahmat belas kasih-Nya. ${ }^{11}$ Jadi fokus utama pewartaan Yesus bukanlah penghakiman oleh Allah tetapi penyelamatan oleh Allah.

Karya penyelamatan Allah itu tidak dinyatakan lewat nubuat profetis tetapi dalam diri seorang pribadi, yaitu Yesus dari Nasaret. Melalui Dia, kuasa anti Allah (iblis) yang menjadi sumber kejahatan dan dosa dihancurkan dan kuasa Allah yang menjadi sumber rahmat dan kebaikan datang kepada manusia. Hal ini, menurut Helmut Merklein, tampak dalam kata-kata Yesus dalam Injil Lukas, “Aku melihat Iblis jatuh dari langit seperti kilat" (Luk 10:18; bdk. Yoh 12:31; Rom 16:20). ${ }^{12}$ Iblis di sini adalah simbol kuasa kegelapan, yaitu sumber dosa dan kejahatan. Dalam kepercayaan di kalangan umat Israel pada saat itu, kuasa iblis ini kelak akan dihancurkan oleh Allah melalui para

10 Di sini menurut ekseget Rudolf Schnackenburg terpenuhilah nubuat Deuteroyesaya tentang keselamatan, kegembiraan dan perdamaian (Yes 52:7). Rudolf Schnackenburg, Gottes Herrschaft und Reich:Eine biblisch-theologische Studie (Freiburg: Herder, 1950), S. 57.

11 Helmut Merklein, Jesu Botschaft, S. 36.

12 Helmut Merklein, Jesu Botschaft, S. 61. 
malaikat tempur-Nya dalam pertarungan akhir zaman. ${ }^{13}$ Tetapi apa yang dinantikan pada akhir zaman oleh apokaliptik, terpenuhi kini dalam diri Yesus. Pertarungan 'akhir' zaman telah ditentukan: Setan telah dikalahkan. Dalam diri Yesus penyelamatan definitif manusia kini telah menjadi kenyataan. Karena itu pula sejak sekarang sejarah Israel dan sejarah umat manusia menjadi sejarah keselamatan.

\section{Kerajaan Allah Sedang Terjadi Sekarang Ini (Dimensi Riil Historis)}

Yesus tidak memisahkan diri dari tradisi Israel yang menantikan kedatangan Kerajaan Allah di masa depan. Hal ini terungkap dalam permohonan doa Bapa Kami: "datanglah kerajaan-Mu" (Luk 11:2) dan sabda bahagia Yesus yang kedua dan ketiga: "Berbahagialah, hai kamu yang sekarang ini lapar, karena kamu akan dipuaskan. Berbahagialah, hai kamu yang sekarang ini menangis, karena kamu akan tertawa" (Luk 6:21). Demikian pula berbagai gambaran tentang perjamuan bersama di masa depan dalam perumpamaan Yesus menunjukkan dimensi futuris Kerajaan Allah. Misalnya: perjamuan bersama Yesus dengan muridmurid-Nya (Luk 22:30; bdk. Luk 14:15), perjamuan Allah dengan bapabapa bangsa (Mat 8:11; Luk 13:28f), Perjamuan pernikahan di masa depan (Luk 14:16-24; Mat 22:1-4), Perjamuan kegembiraan para hamba dengan tuan mereka (Mat 25:14-30; bdk. Luk 12:35-38).

Namun hal yang khas dari pewartaan Kerajaan Allah Yesus adalah bahwa keselamatan (eskatologis) itu sudah mulai terjadi sekarang ini. ${ }^{14}$ Kerajaan Allah bukanlah sesuatu yang dinantikan di masa depan tetapi telah mulai terjadi dalam sejarah hidup ini. Bagi para pendengar Yesus saat itu, warta Kerajaan Allah berkaitan dengan penantian apokaliptis,

13 Pertarungan akhir zaman yang dinantikan oleh apokaliptik antara Allah dan iblis, atau antara Mikael, malaikat terang, melawan Belial, malaikat kegelapan, kini telah terlaksana dengan kemenangan Mikael. Medard Kehl, Dein Reich komme, S. 142.

14 Menurut Merklein, kekhasan pewartaan Yesus yang tak ada bandingannya pada zaman itu adalah bahwa Kerajaan Allah sedang terjadi sekarang ini. "Seni dan cara Yesus, bagaimana pewartaan eskatologis tentang Kerajaan Allah dikaitkan dengan masa kini, adalah sesuatu yang pada zaman Yudaisme tanpa paralel." Helmut Merklein, Jesu Botschaft, S. 63. 
yaitu saat datangnya Allah pada akhir jaman untuk menyatakan diriNya sebagai raja Israel (Zef 3:14-16; Zak 2:13; Dan 12:13). Tetapi harapan masa depan Israel itu kini terpenuhi dalam diri Yesus. ${ }^{15}$

Secara istimewa dalam diri Yesus Kerajaan Allah sungguh hadir nyata dalam hidup manusia. Kerajaan Allah itu kini menyejarah. Ia tidaklah sekedar ungkapan keagungan ilahi (misteri Allah) tetapi sungguh terjadi dalam waktu dan kehidupan historis manusia. Hal ini terjadi karena Yesus, melalui sabda dan karya-Nya, menghadirkan Kerajaan Allah itu dalam hidup manusia. Kekinian Kerajaan Allah tampak dalam sabda Yesus yang membawa kabar gembira dan dalam kuasa karya-Nya yang menyatakan pembebasan, pengampunan dan penyembuhan. “Jika Aku mengusir setan setan dengan jari (tangan kanan) Allah, maka sesungguhnya Kerajaan Allah itu telah datang kepada kamu" (Luk 11:20). Sebab, kuasa iblis sudah dilumpuhkan, maka dapatlah Yesus mewartakan bahwa pengusiran roh-roh jahat yang menjadi penyebab pelbagai kejahatan dan kerusakan dalam hidup manusia merupakan manifestasi historis Kerajaan Allah.

Dengan demikian Yesus merevisi total horison pemahaman apokaliptis tentang Kerajaan Allah. Jika bagi kalangan apokaliptis, dunia sekarang adalah dunia ketidakselamatan, karena itu Kerajaan Allah dinantikan sebagai sesuatu yang terjadi di masa depan, maka bagi Yesus sejarah aktual Israel (baca: umat manusia) tidak lagi sejarah ketidakselamatan, tetapi menjadi sebuah sejarah baru, yaitu sejarah keselamatan dari pihak Allah. Karena Israel-melalui Yesus-dibarui oleh Allah dan dianugerahi penyelamatan, maka sekarang berubahlah situasi Israel. Kini penyelamatan Allah tercurah kepada Israel. Keselamatan Israel kini terjadi tidak melalui ketaatan harafiah terhadap Hukum Taurat ataupun ibadat silih dosa di kenisah Yerusalem, tetapi melalui tindakan kasih, dalam mana kehendak Allah akan perdamaian dan keadilan bagi manusia menjadi nyata.

15 Juergen Becker, Jesus von Nazareth (Berlin-New York: Walter de Gruyter, 1995), S. 148. 
Jadi, warta Kerajaan Allah Yesus tidaklah terpusat pada masa depan, akhir dunia, tetapi dalam pembaruan masa kini melalui tindakan pembebasan kasih Allah. ${ }^{16}$ Juga manakala tindakan ini dalam kaca mata manusiawi tampak begitu kecil dan tersembunyi (seperti biji sesawi atau ragi), toh tindakan ini diresapi oleh dinamika transformatif kasih Allah. Karena itu pula manakala kita membiarkan hidup kita diresapi oleh gerakan perdamaian dan keadilan Allah, di sana pula teretaslah Kerajaan Allah di tengah-tengah kita. ${ }^{17}$

\section{Pembebasan Integral dari Kuasa Dosa}

Kerajaan Allah yang diwartakan oleh Yesus membebaskan manusia secara integral, yaitu pembebasan manusia yang utuh dan menyeluruh dari belenggu yang memisahkannya dari Allah dan sesamanya. Maka, Kerajaan Allah berkaitan dengan pembebasan dari kuasa dosa. Mengapa? Karena akar segala kejahatan yang mengasingkan seseorang dari Allah dan sesamanya adalah dosa. Maka, yang menentukan dalam pewartaan Yesus bukanlah pembebasan sosial politis dari penindasan, juga bukan pembebasan etis personal tetapi pembebasan dari dosa, karena dosa adalah akar retaknya hubungan dengan Allah dan akar dari segala ketidakadilan di muka bumi ini (bdk. Luk 10:18). Karena itu, Yesus mewartakan karya pembebasan manusia dari dosa. Di hadapan Allah, Israel dan bangsa-bangsa lain kini tidak lagi menjadi bangsa yang terbuang dan tidak selamat, tetapi bangsa yang dibebaskan dari kuasa dosa untuk menjadi umat keselamatan Allah. ${ }^{18}$

Tentu saja, pewartaan Kerajaan Allah Yesus meliputi pula pembebasan dalam dimensi sosial politik, manakala tatanan sosial politik

16 Menurut Kehl: “Kerajaan Allah tidak menanti kita seolah-olah seperti sesuatu yang sudah selesai dan mantap di surga atau di dalam dunia yang baru, tetapi ia menampakkan dirinya sebagai peristiwa kasih Allah, yang menerima sejarah aktual kita ke dalam kehidupan Allah yang menyelamatkan dan membebaskan dan dengan itu ia menjadi kian transparan dalam kenyataan historis kita." Medard Kehl, Dein Reich komme, SS. 143-144.

17 Medard Kehl, Dein Reich komme, S. 145.

18 Medard Kehl, Dein Reich komme, S. 143. 
yang ada menimbulkan ketidakadilan sosial dan karena itu tidak sesuai dengan kehendak Allah. Tetapi sangatlah tidak tepat untuk mereduksi Kerajaan Allah pada pembebasan dalam bidang sosial politik saja. Kerajaan Allah Yesus bersifat integral. Ia mencakup pembebasan dari kuasa dosa baik yang terwujud konkret dalam hidup pribadi maupun dalam penderitaan sosial.

Hal ini terlihat nyata dalam pilihan Yesus mendahulukan orangorang miskin. Dasar opsi ini adalah Kerajaan Allah. Dalam khotbah di bukit, Yesus menyampaikan sabda bahagia tentang orang-orang miskin. Mereka adalah pertama-tama orang-orang yang mengalami penderitaan konkret (yang lapar dan menangis). Sabda bahagia mewartakan kehadiran Allah yang akan mengubah situasi ini. Tetapi sabda bahagia tidak berbicara tentang situasi penderitaan sosial ekonomis saja, melainkan juga tentang seluruh Israel yang dikuasai oleh dosa. Situasi penderitaan itu hanyalah wujud dan akibat dosa Israel yang berada dalam situasi ketidakselamatan. Maka, sabda bahagia adalah pewartaan tentang karya penyelamatan Allah yang kini membebaskan Israel (manusia) dari kuasa dosa dan sekaligus dari situasi penderitaan. Israel disebut berbahagia, karena kini kepada mereka dinyatakan karya penyelamatan Allah.

\section{PERWUJUDAN KERAJAAN ALLAH DALAM SABDA DAN KARYA YESUS}

Bagaimanakah Yesus mewujudkan Kerajaan Allah dalam hidupNya? Melalui sabda dan karya-Nya, Yesus menghadirkan karya penyelamatan Allah bagi manusia.

\section{Melalui Sabda-Nya}

Kehadiran Kerajaan Allah dalam hidup Yesus dapat kita temukan pertama-tama melalui sabda-Nya. Ketika tampil untuk pertama kalinya di Galilea, Yesus langsung berkhotbah tentang Kerajaan Allah. Hal ini menjadi tema dan program perutusan diri-Nya. Ia memaklumkan tentang Kerajaan Allah yang "sudah dekat" (Mrk 1:15; Luk 10:9; bdk. Luk 6:20 dan seterusnya). "Dekat" di sini bukan berarti kalender waktu 
tetapi pernyataan keselamatan. Dekat tidak berbicara tentang garis waktu tetapi isi peristiwa, yakni peristiwa kehadiran Allah dalam hidup manusia yang membawa keselamatan. Melalui khotbah perdana-Nya, Yesus memproklamasikan terwujudnya karya penyelamatan Allah kini.

Kenyataan bahwa bagi Yesus Kerajaan Allah adalah sebuah peristiwa, tampak dalam jawaban-Nya atas pertanyaan orang-orang Farisi tentang bilamanakah Kerajaan Allah akan datang: “Kerajaan Allah datang tanpa tanda-tanda lahiriah, juga orang tidak dapat mengatakan: Lihat, ia ada di sini atau ia ada di sana! Sebab sesungguhnya Kerajaan Allah ada di antara kamu" (Luk 17:20-21). Kerajaan Allah merupakan peristiwa kehadiran Allah yang menyelamatkan dalam hidup manusia.

Secara khusus Yesus menyatakan kehadiran Kerajaan Allah melalui perumpamaan perumpamaan-Nya. Misalnya dalam perumpamaan tentang biji sesawi, Yesus melukiskan bagaimana Kerajaan Allah telah mulai tumbuh (Mrk 4:30-32; Luk 13:18 dan seterusnya). Memang, Kerajaan Allah itu belum tampak jelas seperti sebuah pohon besar yang rindang, tetapi ia telah mulai tumbuh dan berkembang seperti halnya biji sesawi. Perumpamaan biji sesawi ini tidak berbicara tentang besar kecilnya Kerajaan Allah tetapi tentang mulai hadirnya Kerajaan Allah dalam hidup manusia. Menurut Helmut Merklein, proklamasi Kerajaan Allah Yesus merupakan bagian dari peristiwa Kerajaan Allah itu sendiri, yang sedang berjalan menuju pemenuhannya sebagaimana biji sesawi yang telah mengandung dalam dirinya akar yang hidup yang sedang berkembang menjadi ranting-ranting rimbun. ${ }^{19}$ Demikian pula perumpamaan Yesus lainnya tentang ragi (Mat 13:33), tentang benih yang tumbuh (Mrk 4:26-29) dan tentang lalang di antara gandum (Mat 13:36 dan seterusnya) melukiskan proses dinamis Kerajaan Allah yang kini sedang terjadi dalam hidup manusia. ${ }^{20}$

Dalam perumpamaan tentang anak yang hilang, Yesus menguraikan lebih jauh isi Kerajaan Allah, yaitu kehadiran Allah yang penuh belas

19 Helmut Merklein, Jesu Botschaft, S. 76.

20 Juergen Becker, Jesus von Nazareth, SS. 152-154. 
kasih dalam hidup manusia (Luk 15:11-32). Perumpamaan ini menampilkan wajah Allah sebagai bapa (ibu) yang penuh kerahiman, yang tidak memperhitungkan dosa-dosa umat-Nya, tidak meng-hukumnya, tetapi yang mengampuninya tanpa syarat. Kisah ini melukiskan kebaikan Allah, yang karya penyelamatan-Nya mendahului sikap pertobatan manusia (bdk. Mat 18:24-27). Ketika melihat anaknya datang dari jauh dan sebelum si anak mengungkapkan tobatnya, sang ayah telah lari menyongsongnya, memeluk dan merengkuhnya dalam kasih kebapaannya serta menghadiahkannya ciuman pengampunan. ${ }^{21}$ Melalui perumpamaan ini, Yesus melukiskan Kerajaan Allah sebagai kehadiran Allah yang penuh kerahiman, yang menghapus masa lalu dosa umatNya secara cuma-cuma dan membuka baginya masa depan keselamatan yang baru.

Tidak kalah pentingnya adalah khotbah Yesus di bukit. Dalam khotbah bahagia, Yesus berbicara tentang situasi penderitaan sosial (ekonomis-politis) umat Israel (Mat 5:3-12; Luk 6:20b-23). Namun situasi penderitaan ini tidak hanya berkaitan dengan kondisi kemelaratan dan kesengsaraan tetapi juga dengan situasi seluruh Israel (dan umat manusia) yang terjerat dalam kuasa dosa. ${ }^{22}$ Karena itu, pernyataan sabda bahagia ditujukan kepada semua orang yang membutuhkan rahmat penyelamatan Allah. Jika sekarang orang miskin dan sengsara dinyatakan bahagia, justru karena kepada mereka kini dinyatakan karya penyelamatan Allah. Jadi, sabda bahagia sesungguhnya menyatakan kehadiran Kerajaan Allah, yaitu Allah yang bertindak untuk menyelamatkan umat-Nya, tidak sekedar dari situasi penderitaan mereka, tetapi dari seluruh situasi ketidakselamatan mereka. ${ }^{23}$

\section{Melalui Karya-Nya}

Hadirnya Kerajaan Allah dalam diri Yesus tampak paling jelas dalam karya-karya-Nya. Melalui pelbagai tindakan-Nya, Yesus menghadirkan

21 Helmut Merklein, Jesu Botschaft, S. 80.

22 Helmut Merklein, Jesu Botschaft, S. 49.

23 Juergen Becker, Jesus von Nazareth, S. 200. 
Allah yang membebaskan dan menyelamatkan dalam hidup manusia. Yang pertama adalah karya mukjizat pengusiran setan. Tindakan ini merupakan tanda merajanya kuasa Allah dalam hidup manusia: "Jika aku mengusir setan dengan 'jari' Allah, itu tandanya Kerajaan Allah telah datang kepadamu" (Luk 11:20; Mat 12:28). Pengusiran setan adalah bukti hancurnya kuasa iblis dan karena itu kuasa Allah kini dapat meraja dalam hidup manusia (bdk. Luk 10:18). ${ }^{24}$

Kemudian Kerajaan Allah terwujud dalam tindakan mukjizat penyembuhan. Tindakan Yesus untuk meyembuhkan orang sakit adalah tanda terpenuhinya peristiwa keselamatan eskatologis (bdk. Mat 9:32 dan seterusnya). Melalui tindakan penyembuhan Yesus ini, peristiwa keselamatan untuk orang sakit dan bahkan untuk orang mati menjadi kenyataan. Berkat karya mukjizat Yesus “orang buta melihat, orang lumpuh berjalan, orang kusta menjadi tahir, orang tuli mendengar, orang mati dibangkitkan" (Mat 11:5; Luk 7:22). Apa yang dinubuatkan oleh para nabi terjadi di masa depan, terwujud di masa kini melalui karya penyembuhan Yesus. ${ }^{25}$

Hal yang tidak boleh dilupakan adalah sikap dan tindakan Yesus terhadap orang berdosa. Injil tak henti-hentinya mengisahkan tentang kasih Yesus yang luar biasa terhadap orang berdosa. Ia memiliki perhatian dan kasih sayang yang besar terhadap pemungut cukai dan pendosa (Mrk 2:15-17; Luk 7:36-50; 19:1-10; Mrk 2:1-12). Ia datang untuk mencari dan menyelamatkan yang hilang (Luk 19:10). Ia bersantap dengan para pendosa. Sebagai konsekuensinya, Ia dihina sebagai teman para pemungut cukai dan pendosa (Luk 7:34b; Mat 11:19b).

Khususnya dalam perjamuan bersama orang berdosa tampak bagaimana Yesus menyatakan kehadiran Allah yang penuh kerahiman bagi umat-Nya yang berdosa. ${ }^{26}$ Dalam perjamuan bersama ini, Allah

24 Helmut Merklein, Jesu Botschaft, S. 64.

25 Yesaya misalnya bernubuat: "Pada waktu itu mata orang-orang buta akan dicelikkan, dan telinga orang-orang tuli akan dibuka. Pada waktu itu orang lumpuh akan melompat seperti rusa, dan mulut orang bisu akan bersorak-sorai" (Yes 35:5-6).

26 Jika dalam injil Yohanes perjamuan Yesus dengan orang berdosa tidak banyak 
pencipta menunjukkan kepada ciptaan-Nya perhatian keilahian-Nya (endzeitliche Fuersorge) dan bertindak penuh belas kasih kepada orang berdosa. Perjamuan bersama orang berdosa dan pengampunan dosa merupakan tanda kehadiran Kerajaan Allah (bdk. Mrk 2:15-17).

\section{PEMBARUAN PEMAHAMAN KRISTOLOGIS DAN EKLESIOLOGIS}

Dari uraian tentang Kerajaan Allah yang menjadi pusat pewartaan Yesus dapat ditarik beberapa hal penting bagi pembaruan pemahaman kristologis dan eklesiologis.

\section{Pemahaman Kristologis}

Sangatlah menarik bagaimana Yesus memproklamasikan Kerajaan Allah. Ia tidak hanya memaklumkan kedatangan Kerajaan Allah, tetapi lebih dari itu mewujudkannya sebagai peristiwa yang terjadi sekarang ini. Yesus menghadirkan Kerajaan Allah dalam seluruh hidup-Nya baik melalui sabda-Nya maupun melalui karya-Nya. Karena itu, Kerajaan Allah berkaitan dengan pribadi-Nya. ${ }^{27}$ Bagi Yesus Kerajaan Allah bukanlah sebuah program dari luar diri dan hidup-Nya, tetapi sudah terwujud dalam diri-Nya sepenuhnya dan seutuhnya. Karena seluruh hidup Yesus merupakan perwujudan Kerajaan Allah, maka Origenes menyebut-Nya sebagai autobasileia (Kerajaan Allah dalam diri/pribadi).

dikisahkan (Yoh 12:2), maka dalam injil sinoptik terdapat banyak sekali kisah ini (Mat 11:18 dan seterusnya; Luk 7:33 dan seterusnya; Luk 10:7; Mat 10:11; Luk 14:15-24; Mat 22:1-10; Mrk 1:31; 2:15 dan seterusnya; 2:18 dan seterusnya; 3:20; 7:1 dan seterusnya; 14:3 dan seterusnya; Luk 8:1-3; 10:8.38 dan seterusnya; 13:26; 14:1 dan seterusnya). Hal ini menunjukkan bahwa perjamuan bersama bagi Yesus memiliki makna yang sangat penting. Menurut Jürgen Becker, ada tiga kekhasan perjamuan bersama Yesus: Perjamuan ini berlangsung di desa-desa Galilea, pesertanya biasanya orang berdosa, dan sebagai wujud terpenuhinya Kerajaan Allah. Juergen Becker, Jesus von Nazareth, S. 201.

27 Di sinilah letak perbedaan utama Kerajaan Allah yang diwartakan oleh Yesus jika dibandingkan dengan pemahaman orang Israel saat itu. Perwujudan dan lokalisasi Kerajaan Allah bagi orang Israel adalah Sion, khususnya kenisah. Sedangkan yang baru dan istimewa bagi Yesus ialah bahwa Ia mengalihkan perwujudan dan lokalisasi ini pada diri-Nya. W. Härle, "Die Basileia-Verkündigung Jesu als implizite Gotteslehre." In Wilfried Härle und R. Preul, Hrsg., Reich Gottes (Marburg: N.G. Elwert, 2003), S. 18. 
Perwujudan paripurna Kerajaan Allah dalam diri Yesus terjadi dalam peristiwa kematian dan kebangkitan-Nya dari alam maut. Dalam peristiwa Paskah, Kerajaan Allah tidak lagi menjadi janji tetapi telah mencapi perwujudannya. Dalam diri Yesus yang bangkit, Kerajaan Allah tidak lagi berziarah menuju kepenuhan tapi telah mencapai kepenuhanNya. Karena itulah berkat peristiwa kebangkitan-Nya, Kitab Suci memberi gelar Ilahi kepada Yesus, yaitu sebagai Mesias/Kristus (Christos: Kis 2:36) dan Putra Allah (Rom 1:4; Kis 13:30,33) serta Tuhan (Kyrios: Flp 2:11; Rom 10:9; 14:9). Melalui gelar-gelar kristologis ini terungkaplah bahwa dalam diri-Nya Kerajaan Allah telah mencapai titik paripurnanya.

Pemenuhan keselamatan eskatologis ini bahkan dilukiskan oleh Kitab Suci Perjanjian Baru sudah terjadi sejak peristiwa kematian Yesus. Injil Matius melukiskan tanda-tanda apokaliptis yang menyertai kematian Yesus (27:51-54), yaitu tiga gejolak dahsyat kosmis: gempa bumi, terbelahnya bukit batu, dan terbukanya kubur-kubur. Gambaran gejolak kosmis ini berasal dari tradisi apokaliptis dan menggambarkan saat keselamatan akhir zaman ketika Allah datang sebagai hakim dan raja semesta alam (bdk. Hag 2:7-10; Zak 14:1-11). Namun, apa yang dinantikan pada akhir zaman, yaitu keselamatan paripurna atau pemenuhan Kerajaan Allah, kini telah terwujud dalam diri Yesus.

Sangatlah menarik pula untuk diamati, bahwa kalau Yesus mewartakan Kerajaan Allah, maka murid-murid-Nya seolah-olah tidak mewartakan hal yang sama tetapi malahan mewartakan tentang Dia. Alasannya kiranya dapat ditemukan dalam kenyataan bahwa Kerajaan Allah itu telah terwujud dalam diri Yesus. Kini Kerajaan Allah itu 'identik' dengan Yesus Kristus. Maka, kalau Gereja apostolis memberi kesaksian tentang Yesus Kristus, hal itu berarti pula bahwa Gereja memaklumkan Kerajaan Allah yang telah mencapai kepenuhannya dalam diri-Nya.

\section{Pemahaman Eklesiologis}

Kerajaan Allah sebagai inti pewartaan Yesus juga memiliki implikasi eklesiologis yang penting, yaitu jati diri Gereja berkaitan dengan Kerajaan 
Allah. Gereja dipanggil untuk melanjutkan pewartaan Kerajaan Allah yang dulu diwartakan dan diwujudkan oleh Yesus. Gereja sebagai persekutuan murid-murid Yesus diutus untuk memberikan kesaksian tentang kehadiran Allah yang penuh belas kasih dan penuh kerahiman dalam hidup manusia. Karena itu, menurut Konsili Vatikan II, Gereja tidak hanya sekedar menjadi tanda Kerajaan Allah tetapi "benih dan awal mula Kerajaan itu di dunia" (LG 5). Gereja memang tidak identik dengan Kerajaan Allah, tetapi seluruh hidup dan penampilan Gereja mestilah sanggup mengungkapkan kehadiran Allah yang menyelamatkan di tengah-tengah umat-Nya.

Di sini terungkap pulalah jati diri Gereja yang sebenarnya. Ia bereksistensi di dunia bukan demi kepentingan dirinya sendiri tetapi bagi yang lain, yaitu demi Kerajaan Allah. Dalam kaitan dengan hal ini Kardinal Joseph Ratzinger (sekarang Paus Benediktus XVI) mengatakan: “Gereja ada bukan untuk dirinya sendiri, melainkan menjadi instrumen Allah, untuk mengantar manusia menuju kepada-Nya dan untuk mempersiapkan momentum, saat 'Allah menjadi segala dalam segalanya'" $(1$ Kor 15,28$) .{ }^{28}$ Tujuan kehadiran persekutuan umat Allah di bumi ini adalah mengantar manusia menuju kepenuhan hidup Ilahi, pemenuhan Kerajaan Allah (LG 9).

Hal ini mengandung konsekuensi pembaruan perutusan Gereja. Kini misi Gereja mesti terarah bukan lagi terutama untuk mencari lebih banyak pengikut atau membaptis orang sebanyak-banyaknya. Perutusan Gereja yang terutama adalah memberikan kesaksian tentang nilai-nilai Kerajaan Allah dalam hidup manusia. Dalam situasi sosial yang pluralistis seperti di Indonesia, perutusan tersebut tampak dalam upaya Gereja untuk menjadi komunitas yang inklusif, yaitu komunitas yang siap berdialog dan bekerjasama dengan "mereka yang berkehendak

28 Joseph Ratzinger, “Die Ekklesiologie der Konstitution Lumen Gentium,” in Joseph Ratzinger, Weggemeinschaft des Glaubens. Kirche als Communio. Festgabe zum 75. Geburtstag, Hrsg. von Schuelerkreis. Redaktion: Stephan Otto Horn und Vinzenz Pfnuer (Augsburg: St. Ulrich Verlag, 2002), S. 111. 
baik" untuk membangun masyarakat manusiawi yang dilandasi dan diresapi oleh nilai kebenaran, keadilan, kejujuran, dan kemajemukan.

\section{PENUTUP}

Kerajaan Allah bukanlah soal tempat atau lingkup kekuasaan, melainkan diri Allah sendiri yang melalui Yesus Kristus kini datang ke dalam sejarah manusia untuk membebaskannya dari belenggu dosa dan kematian, serta menuntunnya menuju kepenuhan hidup (keselamatan). Melalui sabda dan karya-Nya, yang memuncak dalam wafat dan kebangkitan-Nya, Kerajaan Allah itu sungguh-sungguh hadir dalam pribadi Yesus Kristus, sehingga melalui perjumpaan dengan Dia, manusia mengalami kebaikan dan kasih Allah yang tidak terbatas.

Dalam Injil Yohanes, Yesus merumuskan perutusan diri-Nya dalam konteks Kerajaan Allah itu demikian, “Aku datang supaya mereka mempunyai hidup, dan mempunyainya dalam kelimpahan" (Yoh 10:10). Berpangkal dari sini pulalah dapat ditemukan hakikat dan perutusan Gereja yang sejati. Gereja bereksistensi bukan untuk dirinya sendiri, tetapi sebagai "sakramen penyelamatan universal" (LG 1), tanda dan sarana perwujudan bagi yang lain, yaitu bagi Kerajaan Allah. Gereja adalah persekutuan murid-murid Yesus Kristus yang menjadi saksi-saksi kebaikan Allah yang telah memberikan kepada manusia secara cumacuma "hidup dalam kelimpahan." Justru dalam situasi manusia dewasa ini yang masih dikuasai oleh kekerasan, permusuhan, dan egoisme, kesaksian Gereja akan Kerajaan Allah semakin dibutuhkan agar semakin banyak orang mengalami kasih dan kerahiman Ilahi yang menjadi sumber pengampunan, solidaritas, dan damai di bumi ini.

\section{DAFTAR RUJUKAN}

Beasley-Murray, G.R. Jesus and the Kingdom of God. Michigan-Devon: Wm. B. Eerdmans, 1986.

Becker, Juergen. Jesus von Nazareth. Berlin-New York: Walter de Gruyter, 1995. 
Gnilka, Joachim. Jesus von Nazaret: Botschaft und Geschichte. FreiburgBasel-Wien: Herder, 1990.

Härle, Wilfried und R. Preul, Hrsg. Reich Gottes. Marburg: N.G. Elwert, 2003.

Kehl, Medard. Dein Reich komme: Eschatologie als Rechenschaft über unsere Hoffnung. Kevelaer: Topos, 2003.

Merklein, Helmut. Jesu Botschaft von der Gottesherrschaft: Eine Skizze. Stuttgart: Katholisches Bibelwerk, 1989.

J. Ratzinger, "Die Ekklesiologie der Konstitution Lumen Gentium." In J. Ratzinger, Weggemeinschaft des Glaubens. Kirche als Communio. Festgabe zum 75. Geburtstag, Hrsg. von Schuelerkreis. Redaktion: Stephan Otto Horn und Vinzenz Pfnuer. Augsburg: St. Ulrich Verlag, 2002.

Schnackenburg, Rudolf. Gottes Herrschaft und Reich: Eine biblischtheologische Studie. Freiburg: Herder, 1950. 